\title{
Marine tephra in the Japan Sea sediments as a tool for paleoceanography and paleoclimatology
}

Ken Ikehara

\begin{abstract}
Tephra is a product of large and explosive volcanic events and can travel thousands of kilometers before deposition. Consequently, tephra deposits are common in terrestrial, lacustrine, marine, and glacial environments. Because tephra deposition is a geologically synchronous event, tephras constitute important isochrones in the Quaternary sequence, not only in Japan but also throughout the northwest Pacific and its marginal seas. As a result, establishing the chronostratigraphic order of tephra deposits is an effective tool for assessing local and regional stratigraphies and for correlating events among sites. For example, tephrostratigraphy can provide precise chronological constraints for other stratigraphic data, such as magneto- and biostratigraphic data. Spatiotemporal variability in the occurrence and geochemistry of tephras can also be used to trace the magmatic evolution of island arcs and their relationships to regional tectonics. In a paleoclimatic context, tephra deposits allow the correlation of past climate events among terrestrial, lacustrine, and marine environments. Tephrochronology is also a fundamental element used in reconstructing the marine reservoir effect, where the ages of tephra in marine and terrestrial settings are compared. Therefore, tephra is a valuable tool not only in stratigraphy, chronology, and volcanology but also in paleoceanography and paleoclimatology.
\end{abstract}

Keywords: Tephra, Key bed, Japan Sea, Stratigraphy, Chronology, Paleoceanography

\section{Introduction}

Tephra is a product of large, explosive volcanic eruptions, and distal tephra (volcanic ash) can travel thousands of kilometers before it is deposited (e.g., Alloway et al. 2007; Lowe 2011; Costa et al. 2012). As a result, tephra beds occur in marine sediment sequences adjacent to volcanic islands and volcanic arcs associated with subduction zones, such as the Japanese archipelago. Tephra is best preserved in marine and lacustrine environments characterized by continuous sedimentation with little physical disturbance. Under such conditions, even thin tephra beds associated with small, local eruptions or large distal eruptions are preserved. In addition to aquatic settings, tephra beds occur in terrestrial and glacial environments. Although the duration of volcanic eruptions ranges from days to decades, tephra beds originating from relatively

Correspondence: k-ikehara@aist.go.jp

Geological Survey of Japan, National Institute of Advanced Industrial Science and Technology, Tsukuba Central 7, 1-1-1 Higashi, Tsukuba, Ibaraki 305-8567, Japan short-lasting explosive eruptions are considered to be geologically synchronous deposits. Consequently, tephras represent important "key beds", connecting many different environments.

Tephras comprise all the explosive products of volcanic eruptions. These include both fall deposits and those from pyroclastic flows (Lowe 2011). Thus, tephras are mixtures of juvenile and lithic material, where the juvenile matter can be pyroclastics ranging in size from ash (grain size $<2 \mathrm{~mm}$ ) to lapilli $(2-64 \mathrm{~mm}$ ) and even angular blocks or subrounded bombs $(>64 \mathrm{~mm})$. In ash layers, the juvenile particles are mostly made of glass shards. Some tephras also contain specific minerals, such as alkaline feldspar and biotite that permit the absolute age determination of tephra beds using $\mathrm{Ar}-\mathrm{Ar}$ and $\mathrm{K}-\mathrm{Ar}$ dating. In this way, tephras have the potential to provide the depositional ages of marine sediments. Each tephra exhibits different petrographic and geochemical characteristics reflecting its magmagenesis including magma source conditions such as subduction parameters,
黛 Springer

(c) 2015 Ikehara. Open Access This article is distributed under the terms of the Creative Commons Attribution 4.0 International License (http://creativecommons.org/licenses/by/4.0/), which permits unrestricted use, distribution, and reproduction in any medium, provided you give appropriate credit to the original author(s) and the source, provide a link to the Creative Commons license, and indicate if changes were made. 
the geotectonic setting whether oceanic or continental, mantle chemistry, eruption mode, and so on, which are generally known as its geochemical "fingerprint". Individual deposits' fingerprints can be compared, allowing a precise correlation of different tephra beds.

Although bulk sediment grain composition by smear slide observation indicates that glass shards usually account for less than $10 \%$ of the material (e.g., Fujioka 1983), tephra grains are an important component of marine sediments. Geochemical analyses of bulk sediments suggest that dispersed ash commonly accounts for $15-20 \mathrm{wt} \%$ in the Caribbean Sea (Peters et al. 2000) and $\sim 6-60$ wt\% and $\sim 30-35$ wt\% in the northwest Pacific (Scudder et al. 2009, 2014). Both the primary and secondary supply of tephra grains to marine environments exhibit a wide spatial distribution in the world's oceans, especially in the vicinity of volcanic islands. In this paper, I review and explain the benefits of using marine tephra for stratigraphy, chronology, volcanology, paleoceanography, and paleoclimatology using examples primarily from the Japan Sea. Although invisible tephra (dispersed ash or cryptotephra) is important in these applications, I mainly focus on visible tephra in this review because of the paucity of studies on invisible tephra in the Japan Sea sediments.

\section{Reviews}

The Japan Sea and source volcanoes

The Japan Sea is located between the Japanese islands and the Asian continent. The Japanese islands are situated along the confluence of the Eurasian, Philippine, Pacific, and North American plates and have experienced widespread volcanism (Fig. 1). The Japan Sea is also flanked by active volcanoes on Ulleung Island (the Ulleung volcano), Korea, and on the Korean Peninsula (the Baegdusan-or Baitoshan, Changbaishan-volcano), on the border between North Korea and China.

The Quaternary Japanese volcanoes can be divided into two major belts, the east and west Japan volcanic belts (Sugimura 1960). The east Japan volcanic belt is

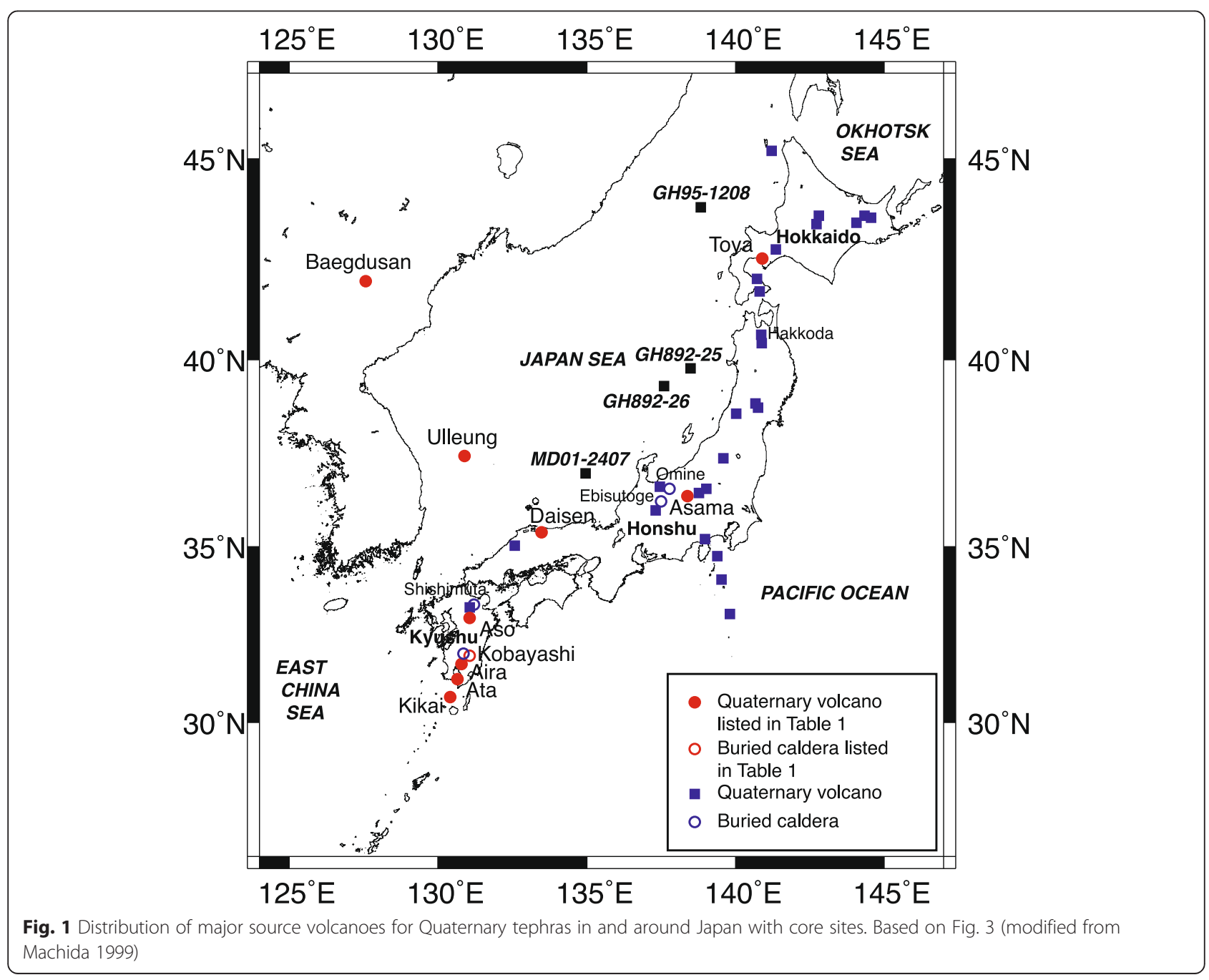


further subdivided into three zones along the Kuril, Northeast Japan, and Izu-Mariana arcs. The west Japan belt comprises volcanoes in western Honshu and Kyushu. Machida (1999) also described two volcanic zones in Japan; the east and west Japan volcanic zones. In the northern part (from Hokkaido to northern Honshu) of the east Japan volcanic zone, large-scale explosive volcanism has been recorded at caldera volcanoes, producing extensive tephra beds. In central Honshu in the east Japan volcanic zone, the volcanoes are stratovolcanoes, both with and without calderas, which have also produced a large volume of tephra and lava. In the west Japan zone, there are abundant large caldera volcanoes in central and southern Kyushu, which have produced ignimbrite flows and widespread tephra deposits, and stratovolcanoes occur in western Honshu. Most volcanoes on the Japanese islands produce lava and tephra with a rhyolitic and andesitic composition. In contrast, both the Ulleung and Baegdusan volcanoes display explosive alkaline to trachytic volcanism, which has resulted in the deposition of numerous distal tephra beds on the floor of the Japan Sea and on the Japanese islands. These tephra beds constitute important the Quaternary-Neogene isochrones in the Japan region (Machida 1999; Nagahashi and Satoguchi 2007; Satoguchi and Nagahashi 2012).

A catalog of the Quaternary volcanoes in Japan was compiled by the Committee for a Catalog of Quaternary Volcanoes in Japan (1999). This work has been extended and presented as a database called "Volcanoes of Japan" (https://gbank.gsj.jp/volcano/index_e.htm). Kuno (1966) proposed a zonal arrangement of volcanic rock series across the Japanese islands, namely the tholeiite, highalumina basalt, and alkali olivine basalt series, respectively, from east to west, and suggested a possible relationship between the depth of the Benioff zone and the volcanic rock series. Aramaki and Ui (1978) collected about 1600 major element analyses from the Japanese Quaternary volcanic rocks and indicated the differences among the volcanic arcs in Japan based on volumeweighted histograms of each element. They also suggested that the generation and ascent modes of caldera-forming felsic magma are different from those of ordinary coneand dome-building basalt-andesite-dacite magma series. Ui and Aramaki (1978) indicated a positive correlation between the $K$ value $\left(\% \mathrm{~K}_{2} \mathrm{O}\right.$ at a given $\% \mathrm{SiO}_{2}$ on a Harker variation diagram: Dickinson and Hatherton 1967; Dickinson 1975) and the depth of the Benioff zone. The elemental compositions of the major Quaternary tephras with some petrographic characteristics were compiled by Machida and Arai (2003). The following are other studies in the literature describing the major elemental composition of volcanic glass shards of the Quaternary-Neogene tephras: the Holocene to the late Middle Pleistocene: Aoki and Arai (2000), Aoki et al.
(2000, 2008), Nagahashi et al. (2004, 2007), Aoki and Machida (2006), and Nagahashi and Ishiyama (2009); the Middle Pleistocene to the Pliocene: Nagahashi et al. (2000), Tamura et al. (2008), Kotaki et al. (2011), and Suzuki et al. (2011); and the Miocene: Hiranaka et al. (2007). Major marine tephra studies around the Japanese islands in locations other than in the Japan Sea include the following: general: Machida and Arai (1983, 1988, 2003) and Furuta et al. (1986); NW Pacific: Fujioka (1983), Cambray et al. (1990), Aoki and Arai (2000), Aoki et al. (2000, 2008), Aoki and Machida (2006), Aoki and Ohkushi (2006), Suganuma et al. (2006), Aoki (2008), and Ikehara et al. (2013); Izu-Bonin: Fujioka et al. (1992a, 1992b) and Nishimura et al. (1992); South of Japan: Ikehara et al. (2006, 2011) and Kutterolf et al. (2014); East China Sea: Cambray et al. (1990) and Moriwaki et al. (2011). Recently, Kimura et al. (2015) determined 10 major and 33 trace elements and $\mathrm{Pb}$ isotope ratios for dacitic to rhyolitic glass shards from 80 widespread tephras erupted during the past $5 \mathrm{Ma}$.

In the Japan Sea, the deep-sea floor is covered by muddy hemipelagic sediments. Their continuous deposition has sealed the tephra in the sediments and created favorable conditions for tephra preservation. Consequently, there is a considerable body of literature on the nature of these marine tephra deposits. For example, Arai et al. (1981) described the occurrence of several tephra beds, including the Kikai-Akahoya (K-Ah), Ulleung-Oki (U-Oki), AiraTanzawa (AT), and Ulleung-Yamato (U-Ym) tephras, in a sediment core from the southern Japan Sea and established a Late Pleistocene to Holocene tephrostratigraphic framework for the region. This work was extended by Machida and Arai (1983). Furuta et al. (1986) described the major elemental compositions of volcanic glass shards in marine tephras, and Ikehara et al. (1994) reported the tephrostratigraphy in the southern Japan Sea and its relationship to the occurrence of dark layers there. This was further extended by Nakajima et al. (1996) and Ikehara (2003) in the central and northern Japan Sea, respectively. Late Pleistocene to Holocene tephrostratigraphy, including invisible tephra, has been studied by Chun et al. (1997, 2006, 2007), Domitsu et al. (2002), Ikehara et al. (2004), Lim et al. (2008, 2013), and Shiihara et al. (2011, 2013). The Ocean Drilling Program (ODP) Legs 127/128 collected long drill cores from the Japan Sea (Shipboard Scientific Party, 1990a, 1990b), and Shirai et al. $(1997,1999)$ reported the major elemental geochemistry of the glass shards of some tephra beds in these cores, correlating them with onshore deposits. Although these reports contain a large amount of Middle Pleistocene tephra in sediments from the Japan Sea (e.g., Shirai et al. 1997, 1999; Chun et al., 2004, 2006, 2007), they do not include all the tephras present in collected the Japan Sea cores. Moreover, no precise, to date, there has been no systematic 
analysis and correlation of tephras in the Early Pleistocene to the Pliocene sediments of the Japan Sea. The major Middle-Late Pleistocene to Holocene tephras are listed in Table 1, and the major elemental geochemistry of glass shards of selected or potential tephras are shown in Table 2.

\section{Occurrence of tephra beds in marine sediments}

Following a subaerial eruption, primary tephra grains are transported through the air before falling onto the water surface and settling through the water column to the sea floor. During the transportation process, grain separation can occur, potentially resulting in the formation of normal and/or reverse grading structures in marine tephra beds. For example, large pumice grains might remain afloat on the water surface for extended periods, settling later, and thus forming the upper part of a tephra bed. Large pumice grains might also be transported by ocean currents, forming a drift pumice layer distal to the main tephra distribution. Examples of drift pumices occur on marine terrace deposits along the Japan Sea coastline (Toyokura et al. 1991; Shiraishi et al. 1992). Explosive submarine volcanism has produced tephra beds (e.g., Yuasa 1995; Chun et al. 2007; Allen et al. 2010). In addition, some marine tephra beds have been deposited by primary pyroclastic material flowing from onshore volcanoes into nearby oceans (e.g., Allen et al. 2012; Schindlbeck et al. 2013; Kutterolf et al. 2014).

Visible tephra deposits can be thick- or thin-bedded and are typically lenticular or have a patchy structure (Fig. 2), depending on factors such as (1) the volume and grain size of the tephra, which are related to eruption volume and transport distance; (2) eruption duration and eruption mode; (3) physical and biological conditions, such as current/wave action and benthos activity; (4) the type of marine sediments; and (5) sedimentation rate. Postdepositional disturbance can render tephra beds invisible.

Secondary (remobilized) volcanic grains are also called "tephras" (e.g., Nagahashi and Kataoka 2014). Because there are several pathways by which tephra grains can be remobilized or reworked, the characteristics of secondary tephra beds are highly variable. One principal of remobilization is gravitational remobilization. For example, where subaerial mass movements on volcanic islands flow into the sea, this material can form subaqueous debris flows containing large amounts of volcanic material (e.g., Masson 1996; Satake and Kato 2001). Similarly, the collapse of steep submarine slopes close to volcanic islands can result in subaqueous gravity flow deposits. Examples of this process are found in the Canary Islands and surrounding deep-sea basins (e.g., Masson 1996; Hunt et al. 2013). A third process, involving the

Table 1 Major Middle-Late Quaternary tephras in the Japan Sea sediments

\begin{tabular}{|c|c|c|c|c|}
\hline Tephra name & Tephra code & Source volcano & & Age (reference) \\
\hline Baegdusan-Tomakomai tephra & B-Tm & Baegdusan volcano & China/North Korea & 10th century (1) \\
\hline Kikai-Akahoya tephra & K-Ah & Kikai caldera & South Kyushu, Japan & $7,165-7,303(2)$ \\
\hline Ulleung-Oki tephra & U-Oki & Ulleung volcano & Ulleung Island, Korea & $10,177-10,225(2)$ \\
\hline Asama-Kusatsu Pumice & As-K & Asama volcano & North Kanto, Japan & $15-16.5$ ka (1) \\
\hline Daisen-Kusatanihara Pumice & KsP or DMs & Daisen volcano & Chugoko, Japan & $20-22$ ka (1) \\
\hline Baegdusan-Vladivostok-oki tephra & $B-V$ & Baegdusan volcano & China/North Korea & $24.5 \mathrm{ka} \mathrm{(3)}$ \\
\hline Aira-Tanzawa tephra & AT & Aira caldera & South Kyushu, Japan & $30,009 \pm 189(2)$ \\
\hline Ulleung-Yamato tephra & $U-Y m$ & Ulleung volcano & Ulleung Island, Korea & 38.2 ka (4) \\
\hline Baegdusan-Japan Basin tephra & $B-J$ & Baegdusan volcano & Chian/North Korea & 50.6 ka (4) \\
\hline Ulleung-Sado-oki tephra & U-Sado & Ulleung volcano & Ulleung Island, Korea & $61.1 \mathrm{Ka}(4)$ \\
\hline Baegdusan-Sado-oki tephra & B-Sado & Baegdusan volcano & China/North Korea & 67.6 ka (4) \\
\hline Baegdusan-Yamato Basin tephra & $\mathrm{B}-\mathrm{Ym}$ & Baegdusan volcano & China/North Korea & 85.8 ka (4) \\
\hline Aso-4 tephra & Aso-4 & Aso caldera & Central Kyushu, Japan & 85-90 Ka (1) \\
\hline Toya tephra & Toya & Toya caldera & Hokkaido, Japan & 112-115 ka (1) \\
\hline Aso-3 tephra & Aso-3 & Aso caldera & Central Kyushu, Japan & 133 ka (5) \\
\hline Ata-Torihama tephra & Ata-Th & Ata caldera & South Kyushu, Japan & 240 ka (1) \\
\hline Aso-1 tephra & Aso-1 & Aso caldera & Central Kyushu, Japan & 250-270 ka (1) \\
\hline Baegdusan-Oga tephra & $\mathrm{B}-\mathrm{Og}$ & Baegdusan volcano & China/North Korea & 448 ka (6) \\
\hline Kobayashi-Kasamori tephra & $\mathrm{Kb}-\mathrm{Ks}$ & Kobayashi caldera & South Kyushu, Japan & 520-530 ka (1) \\
\hline
\end{tabular}

References 1, Machida and Arai (2003); 2, Smith et al. (2013); 3, Ikehara (2003); 4, Lim et al. (2013); 5, Chun et al. (2004); 6, Shirai et al. (1997) 
Table 2 Major elemental composition of the major or potential tephras in Japan Sea sediments

\begin{tabular}{|c|c|c|c|c|c|c|c|c|c|c|c|c|}
\hline Tephra name & Tephra code & $\mathrm{SiO}_{2}$ & $\mathrm{TiO}_{2}$ & $\mathrm{Al}_{2} \mathrm{O}_{3}$ & $\mathrm{FeO}^{*}$ & $\mathrm{MnO}$ & $\mathrm{MgO}$ & $\mathrm{CaO}$ & $\mathrm{Na}_{2} \mathrm{O}$ & $\mathrm{K}_{2} \mathrm{O}$ & Ref. & Remark \\
\hline Baegdusan-Tomakomai tephra & B-Tm & 73.3 & 0.29 & 11.9 & 4.3 & 0.08 & 0.07 & 0.5 & 5.0 & 4.5 & 1 & \\
\hline (Mode 1) & & 75.7 & 0.24 & 10.5 & 4.0 & 0.02 & 0.08 & 0.3 & 4.7 & 4.4 & 1 & Bimodal \\
\hline (Mode 2) & & 68.4 & 0.40 & 14.7 & 4.5 & 0.14 & 0.12 & 1.3 & 5.5 & 5.1 & 1 & \\
\hline Kikai-Akahoya tephra & K-Ah & 75.0 & 0.53 & 13.0 & 2.5 & 0.07 & 0.50 & 2.0 & 3.6 & 2.8 & 1 & \\
\hline Ulleung-3c tephra & $U-3 c$ & 61.20 & 0.58 & 19.20 & 3.11 & 0.15 & 0.36 & 1.56 & 6.36 & 7.48 & 2 & \\
\hline Ulleung-Oki tephra & U-Oki & 61.6 & 0.44 & 20.1 & 2.9 & 0.2 & 0.3 & 1.5 & 6.7 & 6.3 & 1 & \\
\hline Daisen-Kusatanihara Pumice & $\mathrm{KsP}$ or DMs & 72.24 & 0.21 & 16.27 & 1.44 & 0.04 & 0.40 & 2.17 & 4.23 & 3.03 & 3 & \\
\hline Aira-Tanzawa tephra & AT & 78.4 & 0.13 & 12.2 & 1.2 & 0.04 & 0.14 & 1.1 & 3.3 & 3.4 & 1 & \\
\hline Ulleung-Yamato tephra & $U-Y m$ & 57.79 & 0.57 & 19.53 & 3.87 & 0.24 & 0.90 & 4.05 & 6.99 & 6.05 & 4 & \\
\hline Baegdusan-Japan Basin tephra & B-J & 72.01 & 0.15 & 11.12 & 4.79 & 0.14 & 0.02 & 0.45 & 5.89 & 5.42 & 5 & \\
\hline San'in 1 tephra & SAN1 & 76.68 & 0.16 & 12.67 & 0.93 & 0.43 & 0.22 & 1.34 & 3.19 & 4.39 & 5 & \\
\hline Ulleung-Sado-oki tephra & U-Sado & 59.19 & 0.19 & 19.95 & 3.73 & 0.23 & 0.41 & 1.33 & 9.22 & 5.74 & 5 & \\
\hline Baegdusan-Sado-oki tephra & B-Sado & 68.86 & 0.27 & 14.40 & 3.90 & 0.16 & 0.07 & 0.69 & 6.44 & 5.20 & 4 & \\
\hline Baegdusan-Yamato Basin tephra & $\mathrm{B}-\mathrm{Ym}$ & 67.00 & 0.36 & 15.28 & 4.63 & 0.13 & 0.09 & 0.92 & 6.12 & 5.49 & 4 & \\
\hline Aso-4 tephra & Aso-4 & 72.7 & 0.43 & 14.9 & 1.6 & 0.1 & 0.4 & 1.2 & 4.6 & 4.2 & 1 & \\
\hline (Mode 1) & & 73.1 & 0.43 & 14.7 & 1.5 & 0.1 & 0.4 & 1.1 & 4.6 & 4.2 & 1 & Bimodal \\
\hline (Mode 2) & & 72.3 & 0.44 & 15.0 & 1.7 & 0.1 & 0.5 & 1.5 & 4.6 & 3.8 & 1 & \\
\hline Toya tephra & Toya & 79.0 & 0.05 & 12.6 & 1.0 & 0.1 & 0.04 & 0.4 & 4.3 & 2.5 & 1 & \\
\hline Aso-3 tephra & Aso-3 & 71.0 & 0.71 & 15.0 & 2.5 & 0.07 & 0.3 & 1.7 & 3.8 & 4.9 & 1 & \\
\hline Ata-Torihama tephra & Ata-Th & 78.4 & 0.1 & 12.4 & 1.0 & 0.1 & 0.2 & 1.2 & 3.4 & 3.3 & 1 & \\
\hline \multirow[t]{2}{*}{ Aso-1 tephra } & Aso-1 & 65.2 & 0.6 & 14.8 & 3.2 & 0.1 & 0.6 & 2.0 & 3.1 & 4.8 & 1 & \\
\hline & & - & 0.6 & 15.1 & 4.0 & 0.1 & 0.6 & 2.1 & 3.2 & 4.3 & 1 & ${ }^{*} \mid \mathrm{CP}$ \\
\hline Baegdusan-Oga tephra & B-Og & 70.59 & 0.52 & 18.44 & 4.54 & 0.19 & 0.16 & 1.28 & 6.17 & 6.24 & 6 & \\
\hline \multirow[t]{2}{*}{ Kobayashi-Kasamori tephra } & $\mathrm{Kb}-\mathrm{Ks}$ & 74.7 & 0.3 & 14.0 & 1.3 & 0.1 & 0.3 & 1.1 & 4.0 & 4.3 & 1 & \\
\hline & & - & 0.2 & 12.1 & 1.3 & 0.1 & 0.2 & 1.2 & 3.5 & 3.7 & 1 & ${ }^{*} \mid \mathrm{CP}$ \\
\hline Hakkoda 1 tephra (0.75 Ma; reference 9) & $\mathrm{HKd} 1$ or Hkd-Ku & 78.3 & 0.2 & 12.0 & 1.3 & 0.1 & 0.4 & 1.2 & 4.3 & 2.3 & 1 & \\
\hline Shishimuta-Azuki tephra (0.85 Ma; 9) & Ss-Az & 72.3 & 0.5 & 14.8 & 2.6 & 0.1 & 0.0 & 1.6 & 3.5 & 4.7 & 1 & \\
\hline Shishimuta-Pink tephra (1.05 Ma; 9) & Ss-Pnk & - & 0.2 & 12.4 & 1.3 & 0.1 & 0.2 & 1.2 & 3.1 & 4.0 & 1 & ${ }^{*} \mid C P$ \\
\hline \multirow[t]{2}{*}{ Omine tephra (1.65 Ma; 9) } & Omn & 77.9 & 0.1 & 12.8 & 1.0 & 0.1 & 0.1 & 0.9 & 2.7 & 4.5 & 7 & \\
\hline & & - & 0.1 & 10.2 & 1.3 & 0.1 & 0.1 & 1.0 & 3.1 & 4.4 & 1 & ${ }^{*} \mid \mathrm{CP}$ \\
\hline \multirow[t]{2}{*}{ Ebisutoge-Fukuda tephra (1.75 Ma; 9) } & Ebs-Fkd & 76.8 & 0.1 & 13.1 & 1.5 & 0.1 & 0.0 & 0.9 & 2.9 & 4.4 & 7 & \\
\hline & & - & 0.1 & 9.8 & 1.7 & 0.1 & 0.1 & 1.0 & 3.2 & 4.4 & 1 & ${ }^{*} \mathrm{ICP}$ \\
\hline Znp-Ohta tephra (3.9 Ma; 9) & Znp-Oht & - & 0.03 & 12.26 & 1.18 & 0.08 & 0.01 & 0.59 & 3.30 & 4.46 & 8 & ${ }^{*} \mid \mathrm{CP}$ \\
\hline
\end{tabular}

References: 1, Machida and Arai (2003); 2, Shiihara et al. (2011); 3, Domitsu et al. (2002); 4, Lim et al. (2013); 5, Ikehara et a.l (2004); 6, Shirai et al. (1997); 7, Nagahashi et al. (2000); 8, Tamura et al. (2008); 9, Satoguchi and Nagahashi (2012). Total iron is shown as FeO*. Elemental composition analyzed by inductively coupled plasma (ICP) method is shown as *ICP

river transport of terrestrial pyroclastic material to marine environments, has been invoked to explain the coarse fraction composition of shelf sediments adjacent to Kyushu and Shikoku (Arita and Kinoshita 1990; Ikehara 2000, 2013). Similarly, the concentration of bubble-wall-type volcanic glass shards along the path of the modern Kuroshio Current from south Kyushu suggests that glass shards are transported by the Kuroshio Current (Ikehara 2015). Together, these primary and secondary transportation pathways account for the broad geographic distribution of tephra grains in marine sediments and render tephra an important component of marine sedimentation.

\section{Identification and correlation of tephra}

Because the petrographic and geochemical characteristics of tephra grains vary greatly from deposit to deposit, these characteristics can be used to "fingerprint" individual tephra units, allowing any tephra bed to be correlated with established terrestrial and marine tephra 


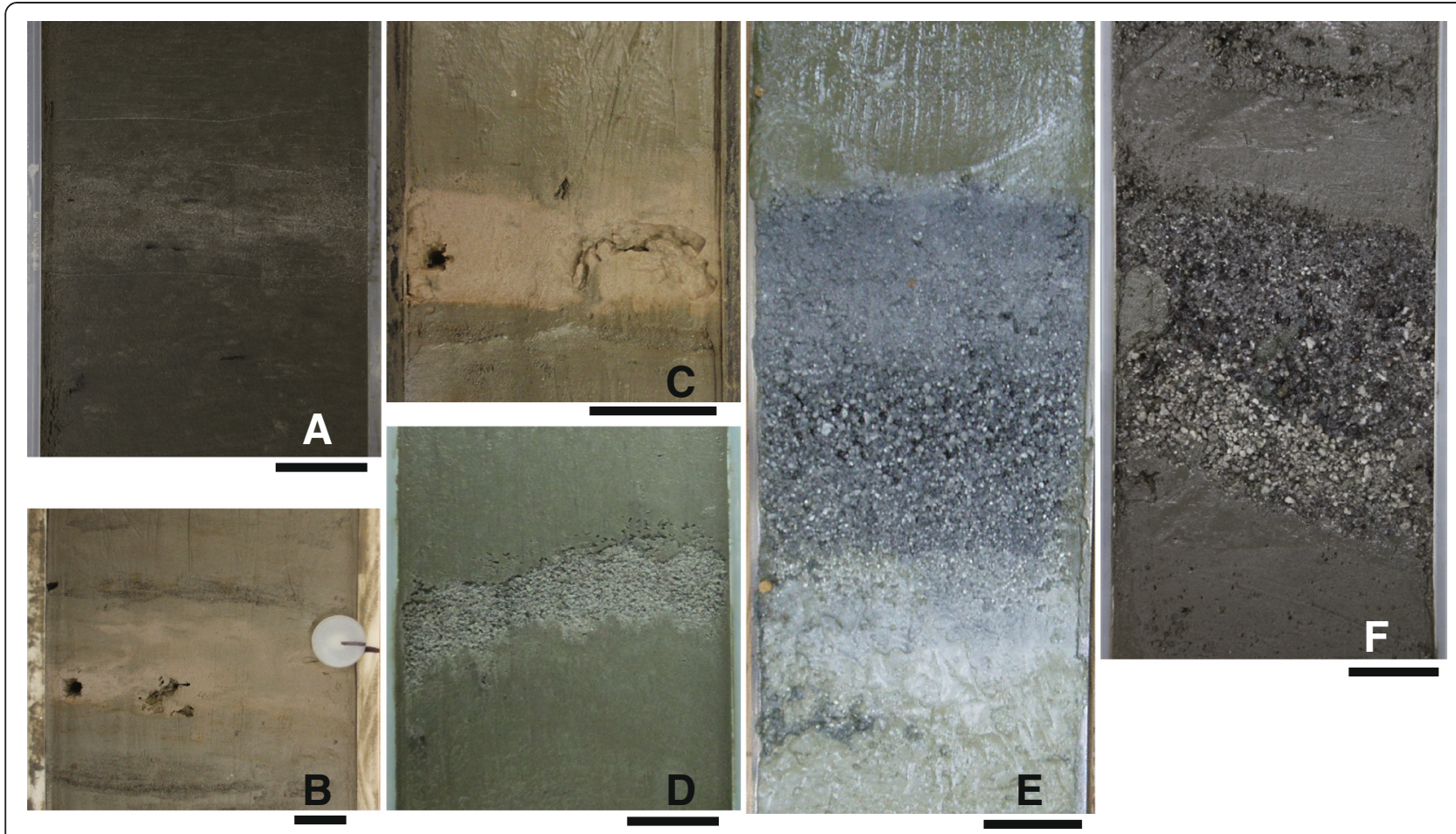

Fig. 2 Variability in tephra occurrence in marine cores (the scale bar is $2 \mathrm{~cm}$ ). a Tephra patches or spots. b Bioturbated tephra bed. c Fine-grained tephra bed with sharp bottom and top boundaries. $\mathbf{d}$ Coarse-grained and pumiceous tephra bed with sharp bottom and top boundaries $\mathbf{e}$ Tephra bed composed of lower fine-grained (light), middle pumiceous coarse-grained (black), and upper fine-grained (gray) parts. f Reworked tephra bed including coarse lithic grains

records. Standard parameters for characterizing tephra include the following: (1) its heavy and light mineral assemblages; (2) the morphology, color, and grain size of the glass shards; (3) the refractive indices of the glass shards and heavy minerals; (4) the major and minor chemical compositions of the glass shards and heavy minerals; and (5) the trace elemental and isotopic compositions of the glass shards (Machida 1999). Combining these petrographic and geochemical characteristics with stratigraphic information is essential for identifying and correlating the tephras (Machida 1999; Machida and Arai 2003). Coupling the refractive index of the glass shards with the glass morphology and heavy and light mineral compositions is a popular method characterizing tephras in and around Japan. The thermal immersion method (e.g., Danhara et al. 1992) is usually used to measure refractive index. There are some datasets on the refractive indices of glass shards and some heavy minerals for Japanese tephras (e.g., Machida and Arai 2003). This is an advantage for using this petrographic methodology in and around Japan. Measurements of the major elements in glass shards are done using an electron microprobe analyzer (EPMA), which is preferable, or with an energy dispersive X-ray spectroscopy analyzer (EDS) adjusted to an electron microscope. For trace elements laser ablation or solution, inductively coupled plasma mass spectrometry (ICP-MS) and instrumental neutron activation (INAA) are employed. The major elemental compositions of glass shards in the widespread Middle Pleistocene to the Holocene tephras in and around Japan are also listed by Machida (1999) and Machida and Arai (2003). Continuous bulk INAA analysis is also used to detect invisible tephras in marine sediment cores (Lim et al. 2008).

\section{Tephra as a stratigraphic tool}

As mentioned above, tephra beds constitute "key" stratigraphic horizons for correlating events among numerous cores and sites. Correlation of tephra beds that are present in different cores can be used to identify the same stratigraphic horizons exactly, even when the tephra is unknown. The recent development of a tephra catalog for the Japan region, mainly based on terrestrial investigations (e.g., Machida and Arai 2003), allows accurate identification and correlation of offshore and onshore tephra beds over a broad area.

The Late Pleistocene to the Holocene sediments in the Japan Sea are characterized by alternations of fine light and dark clayey layers, reflecting variability in the paleoenvironment (e.g., Oba et al. 1991; Tada et al. 1992, 
1999; Ikehara 2003; Kido et al. 2007). The broad occurrence of these changes is indicated by the synchronous incidence of dark layers among the three sites of ODP Legs 127/128 (Tada et al. 1992). To facilitate crucial intercore correlation, one known tephra (Aso-4) and several unidentified deposits were used as "key" beds, together with the occurrence of dark layers. The relationship between the tephras and dark layers was investigated in detail by Nakajima et al. (1996) and Ikehara (2003), who studied the visible tephras of the central and northern Japan Sea, respectively. Lim et al. (2013) extended the investigation in the central Japan Sea to also include invisible tephra (cryptotephra) beds, and thereby confirmed the basinscale synchronicity of the dark layers during marine isotope stages (MIS) 3-5 (Fig. 3). These examples demonstrate the utility of tephra bed identification and characterization in intercore and intersite correlations.
The combination of dark-layer stratigraphy and tephra characterization has also helped to distinguish tephra beds, originally believed to be the same tephra, as separate tephras originating from the same volcano. Some tephras from the same source volcano but from different eruptions have similar petrographic and geochemical characteristics, so it is very difficult to distinguish between them based solely on these attributes. However, because the dark layers in the Japan Sea sediments are synchronous across the whole basin, each individual tephra should always occur in the same position relative to the dark layer stratigraphy. For example, in their recent study of a core collected from the southern Japan Sea, Chun et al. (2007) identified two alkaline tephras in the MIS 3 sequence. While geochemical fingerprinting was able to correlate the upper tephra to the U-Ym bed reported by Arai et al. (1981), the lower tephra occurred

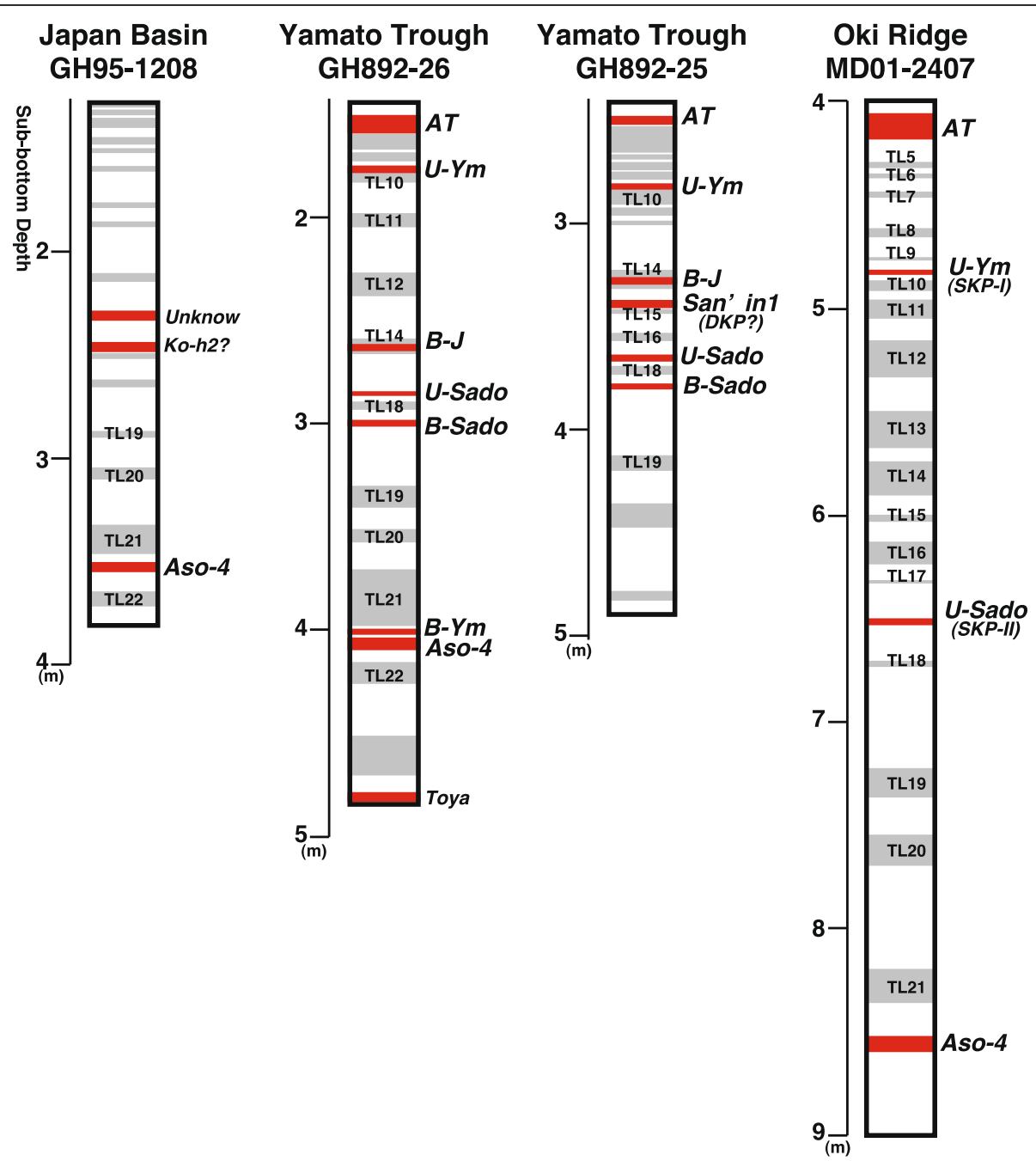

Fig. 3 Tephra occurrences in marine sediment cores during MIS 3-5.3 from the Japan Sea. GH95-1208: Ikehara (2003), GH892-25-26: Ikehara et al. (2004) and Lim et al. (2013), MD01-2407: Chun et al. (2007) 
within a horizon corresponding to the dark-layer stratigraphy where the U-Ym tephra can be found in another basin, described by Nakajima et al. (1996). This discrepancy indicates that the U-Ym tephra reported by Nakajima et al. (1996) was not identical to the original unit described by Arai et al. (1981). Therefore, Chun et al. (2007) renamed the lower tephra "SKP-II," whereas Lim et al. (2013) recently revised the name to "U-Sado." In summary, the dark-layer stratigraphy of the Japan Sea sediments continues to help us refine the Late Pleistocene to the Holocene tephrostratigraphy in this region. The relationship of the Late Pleistocene to the Holocene tephrostratigraphy with dark-layer stratigraphy is summarized in Fig. 4.

Tephra correlation also provides important stratigraphic information on highly bioturbated and massive hemipelagic units. For example, the U-Oki tephra, which erupted from Ulleung Island (Arai et al. 1981), is a wellknown feature of the last deglacial sequence in the southwestern Japan Sea and adjacent land areas. This tephra was first identified and described in marine sediments (Arai et al. 1981) and then correlated with the U2 tephra on Ulleung Island itself (Machida et al. 1984). The majority of deglacial-age Ulleung tephras in the Japan Sea have since been correlated with the U-Oki tephra bed, largely on the basis of their petrographic characteristics (e.g., Machida et al. 1984; Yoshikawa and Inouchi 1993; Takata et al. 2006; Danhara et al. 2010). Recently, however, Shiihara et al. $(2011,2013)$ analyzed the major geochemistry of the glass shards and identified two types of Ulleung tephra in the deglacial sediments from the Japan Sea. They concluded that there are two deglacial Ulleung tephras: one is the U-Oki tephra, which correlates with the onshore U-3 bed, and the other is a new tephra that correlates with the onshore U-4 bed. This finding indicates that detailed characterization of each tephra bed using several methodologies is essential for accurate tephra correlation.

\section{Tephra as a chronological tool}

The eruption ages of several widespread tephras have been estimated using magneto-, bio-, and isotopic stratigraphy. Therefore, identifying these tephras in marine cores provides a basis for constructing robust age models in those marine sediments. At the same time, well-dated marine cores with high-resolution oxygen isotope stratigraphies can provide the depositional ages of marine tephras (e.g., Oba 1991; Aoki and Arai 2000; Chun et al. 2004; Aoki 2008; Aoki et al. 2008). The majority of well-dated tephras are concentrated in the Late Pleistocene to the Holocene sequences, although there are several reports of the Middle Pleistocene tephras in the Japan Sea sediments (e.g., Shirai et al. 1997, 1999). Some Middle Pleistocene tephras are preserved in uplifted onshore marine sequences throughout the Japan Sea basin (Shirai et al. 1997). Widespread tephras of Plio-Pleistocene age have also been reported in onshore marine and lacustrine sequences in Japan (Nagahashi and Satoguchi 2007; Tamura et al. 2008; Satoguchi and Nagahashi 2012). Correlating samples with such tephras is crucial to establishing the robust ages of long marine sequences, such as cores from the International Marine Global Change Study (IMAGES) and ODP/Integrated Ocean Drilling Program (IODP). These correlations can be useful for dating and correlating homogeneous hemipelagic sequences that have fewer age controls, as in the case of lithostratigraphic unit 2 (a heavily bioturbated homogeneous diatom ooze and diatomaceous clay: 6.5-2.5 Ma) from the ODP cores in the Japan Sea as reported in Tada (1994). Some extremely large eruptions have also supplied tephra to pelagic environments located several thousands of kilometers from the source volcano (e.g., Aoki et al. 2000; Suganuma et al. 2006). In such environments, where there are few biostratigraphic signals because the water depth is so great, tephra is even more valuable as a tool for determining the sedimentation age. Ultimately, in combination with highresolution and high-accuracy stratigraphic methods, such as magneto-, bio-, isotopic, and lithostratigraphy, tephrostratigraphy can provide more reliable and detailed age constraints for marine sediment sequences.

Some tephras contain specific minerals that can be used for absolute age determination. For example, alkaline tephras derived from the Ulleung and Baegdosan volcanoes contain alkaline feldspar, while several PlioPleistocene tephras, such as the Znp-Ohta (3.95 Ma) and Omine (or Omine-SK110: $1.65 \mathrm{Ma}$ ) tephras (Tamura et al. 2008), contain biotite phenocrysts. Both are target minerals for Ar-r and $\mathrm{K}-\mathrm{Ar}$ dating. Zircon and apatite minerals are also suitable for fission track dating (e.g., Iwano and Danhara 1998; Danhara and Iwano 2001). Therefore, depending on the mineralogy, tephras themselves can provide absolute ages.

\section{Tephra as a signal of volcanic evolution}

The geochemical and petrographic characteristics of tephra grains provide valuable insight into the nature of the source magma. Therefore, the spatiotemporal variability in tephra characteristics can reflect the magmatic evolution of volcanic islands and island arcs. For example, several researchers have inferred volcanic-tectonic relationships from the spatiotemporal changes in the geochemistry of the Neogene to the Quaternary volcanic rocks (Kimura et al. 2003, 2005; Yoshida et al. 2014). Moreover, because of the high degree of preservation of volcanic glass in deep-sea sediments, the marine tephras from long ODP/IODP cores are potentially amenable to similar analysis. 


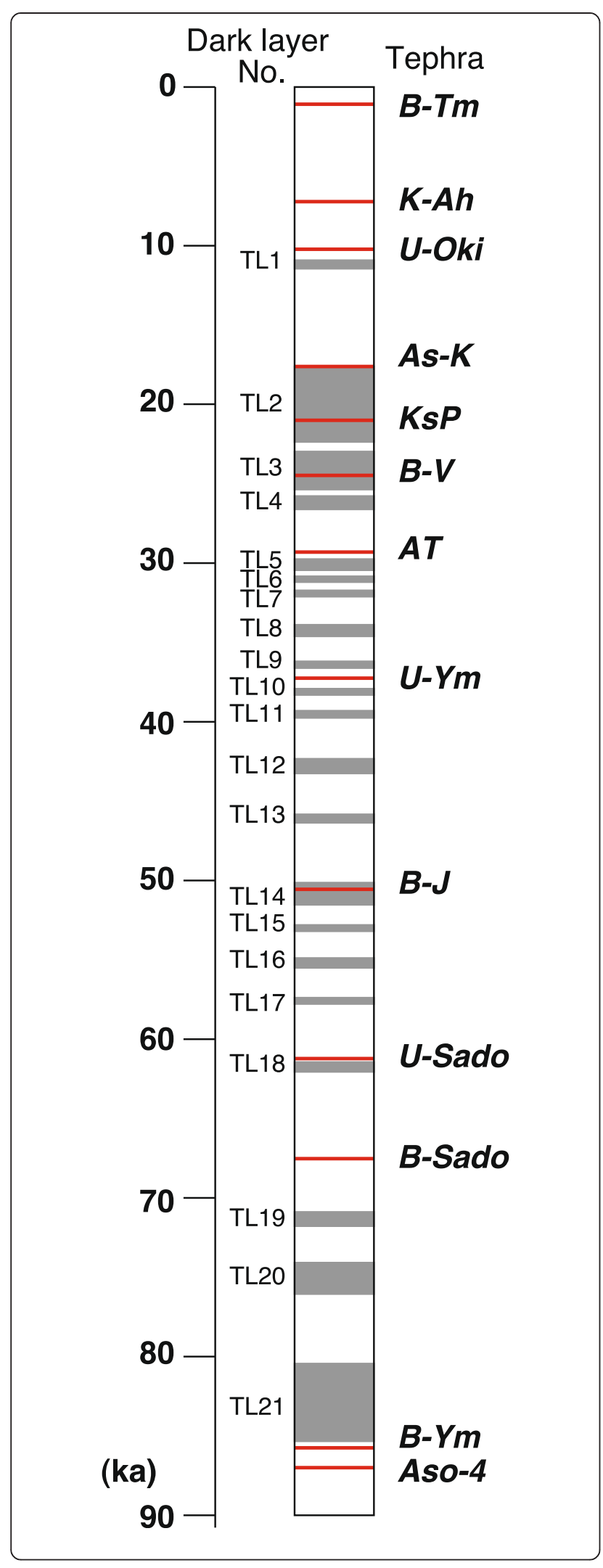

Fig. 4 Dark-layer stratigraphy and tephra occurrences in the Japan Sea during the last $90 \mathrm{ka}$. Dark-layer stratigraphy from Tada et al. (1999). Tephrostratigraphy was compiled from Ikehara et al. (1994), Nakajima et al. (1996), Domitsu et al. (2002), Ikehara (2003), and Lim et al. (2013)

Marine tephra records also provide information on long-term changes in volcanism, such as eruption frequency and intensity, both of which can be influenced by regional tectonics. For example, Machida (1987) used tephras to reconstruct the history of large eruptions from Japanese caldera volcanoes over the last $120 \mathrm{ka}$. In contrast to onshore sequences where erosion can compromise the integrity of depositional sequences, precluding their use in long-term reconstructions, marine records are generally continuous in nature. Furthermore, although it may not be practicable to collect long marine cores from all Japanese waters, the use of marine records can provide considerable insight into the frequency and volume of each volcano's eruptions (e.g., Fujioka 1983). An example of this type of reconstruction is found on the Pacific seafloor offshore Central America. Kutterolf et al. (2008a) correlated marine tephras with Central American eruptions using 56 marine cores and 213 tephra beds. Kutterolf et al. (2008b) recalculated the erupted volumes and masses and related them to changes along the arc.

The long-term occurrence of tephra in the Japan Sea ODP cores was reported by Pouclet and Scott (1992). Based on the number and thickness of the tephra beds per $100 \mathrm{ka}$ at ODP Site 798 and Hole 799A, they established six stages of tephra deposition. Both the number and thicknesses of the beds were high during the last 1.2-1.3 Ma (stages V1 and V2), suggesting that modern volcanic conditions commenced around this time. Before 1.2-1.3 Ma, the number of tephra beds was relatively low (Pouclet and Scott 1992), although deposition of rare but thick tephra beds occurred during this period. Referring to the respective data of Pouclet and Scott (1992), we also see that minor differences between the investigated core sites may reflect spatial differences in volcanic activity. Ultimately, comparing tephra occurrences among drilling sites will yield important information on the spatial variation of volcanism throughout the Japanese islands.

The volcanic source area for the individual PlioceneMiddle Pleistocene tephras is unknown (Satoguchi and Nagahashi 2012). Tamura et al. (2008) estimated the volcanic source areas of some Pliocene-Early Pleistocene deposits from the thickness distributions of the tephra beds. However, there are too few onshore outcrops in which each tephra is exposed to determine source areas from onshore data like composition, grain size, and bed thickness. However, long marine cores have the potential 
to provide information on the spatial distribution of tephra composition, grain size, and bed thickness required to estimate volcanic source areas.

\section{Tephra as a paleoceanographic and paleoclimatological tool}

Because tephra falls in multiple environments, tephra deposits can be used as key beds to correlate events among sites (Ikehara and Okazaki 2014). For example, fluctuations in East Asian monsoons are thought to be recorded in the sediments of Lake Biwa (Kuwae et al. 2002; Nakagawa et al. 2008), Lake Suigetsu (Nakagawa et al. 2003), and the Japan Sea (Tada et al. 1999; Ikehara 2003; Tada 2004; Ikehara and Fujine 2012). Because Lake Biwa and Lake Suigetsu are located close to the Japan Sea, several tephras found in Lake Biwa (Yoshikawa and Inouchi 1993; Nagahashi et al. 2004; Satoguchi et al. 2008) and Lake Suigetsu (Smith et al. 2013), such as the K-Ah, U-Oki, AT, and Aso-4 tephras, also occur in the Japan Sea (e.g., Arai et al. 1981; Furuta et al. 1986; Nakajima et al. 1996) and can therefore connect those different depositional environments.

To better understand the climate system, it is important to compare the timing of changes recorded in different environments. Therefore, paleoclimatologists must ascertain the leads and lags for each climatic and/or environmental event, and tephra allows them to do so. For example, a comparison of the paleoclimatic variability recorded in Lake Suigetsu and Lake Biwa sediments with events in the Japan Sea facilitates the assessment of marine (Japan Sea) and terrestrial (onshore Japan) climatic interactions, and by extension, the Asian monsoon system. When this is coupled to the high-resolution Lake Suigetsu chronology (Bronk Ramsey et al. 2012), it is also possible to explore the role of the Asian monsoon in the global climate system. Furthermore, although the Japan Sea paleoenvironmental record may differ from those of the Pacific Ocean and other marginal seas (e.g., the South and East China Seas, Okhotsk Sea, and Bering Sea), the broad distribution of tephras potentially allows the correlation of past climatic and environmental variations across a wide area.

Tephras can also be used to reconstruct the magnitude of the marine reservoir effect. The eruption ages of the Late Pleistocene to the Holocene terrestrial tephras are generally determined with radiocarbon dating of (a) tree trunks buried in pyroclastic and ashfall deposits or (b) peat beds located above and below the tephra bed. In these subaerial settings, plants obtain carbon directly from the atmosphere and are therefore in equilibrium with atmospheric $\mathrm{CO}_{2}$. In contrast, the eruption ages of the Late Pleistocene to the Holocene marine tephras are typically determined with the radiocarbon dating of associated planktonic foraminifera, which obtain carbon from the surface waters. Consequently, because tephra forms geologically synchronous key beds, the magnitude of the marine reservoir effect at the time of eruption can be established by comparing the terrestrial and marine radiocarbon dates (Fig. 5; Sikes et al. 2000; Siani et al. 2001; Ascough et al. 2004, 2005; Eiriksson et al. 2004; Hutchinson et al. 2004; Larsen et al. 2006; Ikehara et al. 2011, 2013).

Because the ${ }^{14} \mathrm{C}$ concentration of surface seawater differs from that of the atmosphere, evaluating the marine reservoir effect is crucial to accurately calibrate marine radiocarbon dates with calendar ages. The marine reservoir effect is composed of the global mean effect $(R)$ and the local effect $(\Delta R)$ (Stuiver et al. 1986). The global mean effect is approximately 400 years, based on a simple box model calculation (Stuiver et al. 1986; Stuiver and Braziunas 1993), whereas the magnitude of local effects is influenced by ocean circulation and upwelling. For example, in the subarctic northwestern Pacific, upwelling of "old" seawater produces a larger local radiocarbon offset than in the subtropical western Pacific or along the Kuroshio Current (Marine Reservoir Correction Database, http://www.calib.qub.ac.uk/marine/). Today, the North Pacific is the terminus for global deep water circulation (Broecker et al. 1985), so deep water in the North Pacific contains old carbon from the decomposition of sunken organic matter that accumulated during global circulation. The upwelling of this old seawater accounts for the large $\Delta R$ in the North Pacific region.

Both surface water circulation and water ventilation in the Japan Sea have oscillated over orbital and millennial time scales during the Late Pleistocene to the Holocene, reflecting glacio-eustatic sea level and East Asian monsoon fluctuations (Oba et al. 1991; Tada et al. 1999: Itaki et al. 2004; Watanabe et al. 2007; Usami et al. 2013). These could affect the magnitude of the marine reservoir effect. As mentioned above, several tephras occur in both the Japan Sea and Lake Suigetsu. The ages of the Lake Suigetsu deposits are constrained by more than 500 radiocarbon dates from terrestrial leaves and other plant remains (Bronk Ramsey et al. 2012). Comparing the radiocarbon dates of the tephras in the Japan Sea with those from Lake Suigetsu allows the reconstruction of both the spatiotemporal changes in $\Delta R$ and their relationships to paleoceanographic and paleoclimatic changes. Therefore, determining the ages of the marine tephras in Japan Sea sediments is crucial to paleoceanographic studies of the Japan Sea.

\section{Conclusions}

This study has explored the utility of marine tephra records in stratigraphy, chronology, volcanology, paleoceanography, and paleoclimatology in the context of the Japanese 


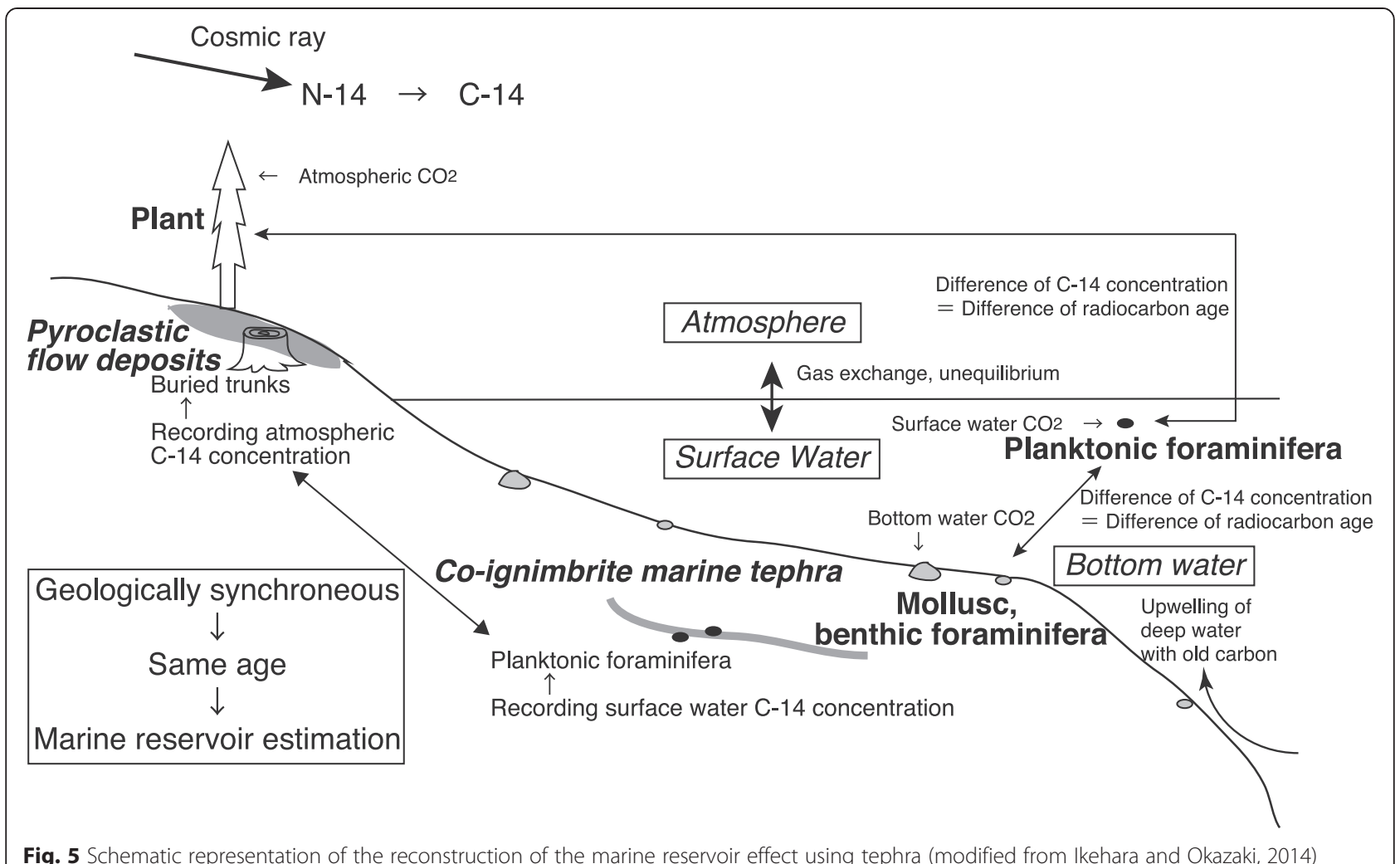

Fig. 5 Schematic representation of the reconstruction of the marine reservoir effect using tephra (modified from Ikehara and Okazaki, 2014)

islands. As a product of explosive volcanism, tephra provides important isochrones for terrestrial, lacustrine, and marine sequences in and around Japan. Because of the large number of tephra beds in Japanese waters, marine tephra is an ideal tool that can be used in many fields of earth science, particularly paleoceanography and paleoclimatology. Marine tephras are crucial in understanding the Asian monsoon system and its relationship with the global climate, as demonstrated by the comparison of paleoclimatic events recorded in Lake Biwa and Lake Suigetsu sediments with those recorded in the Japan Sea.

\section{Abbreviations}

IMAGES: International Marine Global Change Study; IODP: Integrated Ocean Drilling Program; MIS: marine isotope stage; ODP: Ocean Drilling Program.

\section{Competing interests}

The author declares that he has no competing interests.

\section{Authors' contributions}

$\mathrm{Kl}$ proposed the review topic and composed the manuscript.

\section{Acknowledgements}

I would like to express my thanks to Prof. Richard W. Murray (Boston University) and Prof. Ryuji Tada (University of Tokyo) for the opportunity to write this manuscript. I also wish to thank Prof. Steffen Kuttrolf and an anonymous reviewer for their constructive comments.
Received: 29 April 2015 Accepted: 26 October 2015

Published online: 16 November 2015

\section{References}

Allen SR, Fiske RS, Tamura T. Effects of water depth on pumice formation in submarine domes at Sumisu, Izu-Bonin arc, western Pacific. Geology. 2010;38:391-4.

Allen SR, Freundt A, Kurokawa K. Characteristics of submarine pumice-rich density current deposits sourced from turbulent mixing of subaerial pyroclastic flows at the shoreline: field and experimental assessment. Bull Volcanol. 2012;74:657-75

Alloway BV, Larsen G, Lowe DJ, Shane PAR, Westgate JA. Tephrochronology. In: Elias SA, editor. Encyclopaedia of quaternary science. London: Elsevier; 2007. p. 2869-98.

Aoki K. Revised age and distribution of ca. 87 ka Aso-4 tephra based on new evidence from the northwest Pacific Ocean. Quat Intern. 2008:178:100-18.

Aoki K, Arai F. Late Quaternary tephrostratigraphy of marine core KH94-3, LM-8 off Sanriku, Japan. The Quat Res (Daiyonki-kenkyu). 2000;39:107-20 (In Japanese with English abstract).

Aoki K, Machida H. Major element composition of volcanic glass shards in the late Quaternary widespread tephras in Japan — distinction of tephras using $\mathrm{K}_{2} \mathrm{O}-\mathrm{TiO}_{2}$ diagrams. Bull Geol Surv Japan. 2006;57:239-58 (In Japanese with English abstract).

Aoki K, Ohkushi K. Nigorikawa tephra recognized in the sediment core MD01-2409 collected off the Shimokita Peninsula. The Quat Res (Daiyonki-kenkyu). 2006:45:257-60 (In Japanese).

Aoki K, Yamamoto H, Yamauchi M. Late Quaternary tephrostratigraphy of marine cores collected during "Mirai" MR98-03 and MR99-K04 cruises. Tech Rep JAMSTEC. 2000;41:49-56 (In Japanese with English abstract).

Aoki K, Irino T, Oba T. Late Pleistocene tephrostratigraphy of the sediment core MD01-2421 collected off the Kashima coast, Japan. The Quat Res (Daiyonki-kenkyu). 2008:47:391-407 (In Japanese with English abstract). 
Arai F, Oba T, Kitazato H, Horibe S, Machida H. Late Quaternary tephrochronology and paleo-oceanography of the sediments of the Japan Sea. The Quat Res (Daiyonki-kenkyu). 1981;20:209-30 (In Japanese with English abstract).

Aramaki S, Ui T. Major element frequency distribution of the Japanese Quaternary volcanic rocks. Bull Volcanol. 1978;41:390-407.

Arita M, Kinoshita Y. Sedimentological map off Cape Muroto. Mar Geol Map Series. 1990;37:36. Geological Survey of Japan. (In Japanese with English abstract).

Ascough P, Cook GT, Dugmore AJ, Barber J, Higney E, Scott EM. Holocene variations in the Scottish marine radiocarbon reservoir effect. Radiocarbon. 2004;46:611-20

Ascough P, Cook G, Dugmore A. Methodological approaches to determining the marine radiocarbon reservoir effect. Prog Phys Geogr. 2005;29:532-47.

Broecker WS, Peteet DM, Rind D. Does the ocean-atmosphere system have more than one stable mode of operation? Nature. 1985;315:21-6.

Bronk Ramsey C, Staff RA, Bryant CL, Brock F, Kitagawa H, van der Plicht J, et al. A complete terrestrial radiocarbon record for 11.25 to $52.8 \mathrm{kyr}$ BP. Science. 2012;338:370-4.

Cambray H, Guichard F, Fujioka K, Pouclet A, Cadet J-P. Tephrochronologic study of two piston cores off Japan. Bull Volcanol Soc Japan. 1990;35:313-22.

Chun JH, Han SJ, Cheong D. Tephrostratigraphy in the Ulleung Basin, East Sea: Late Pleistocene to Holocene. Geosci J. 1997;1:154-66.

Chun JH, Ikehara K, Han SJ. Evidence in Ulleung Basin sediment cores for a termination II (penultimate deglaciation) eruption of the Aso-3 tephra. The Quat Res (Daiyonki-kenkyu). 2004;43:99-112.

Chun JH, Cheong D, Han SJ, Huh S, Yoo HS. Tephrostratigraphy and paleoenvironments of marine core in the Kita-Yamato Trough, East Sea/ Japan Sea. Korea Soc Econ Environm Geol. 2006;39:83-93 (In Korean with English abstract).

Chun JH, Cheong D, Ikehara K, Han SJ. Age of the SKP-I and SKP-II tephras from the southern East Sea/Japan Sea: implications for interstadial events recorded in sediment from marine isotope stages 3 and 4. Palaeogeogr Palaeoclimat Palaeoecol. 2007;247:100-14.

Committee for a catalog of Quaternary volcanoes in Japan. Catalog of Quaternary volcanoes in Japan, ver. 1.0 (CD-ROM). Volcanol Soc Japan. 1999.

Costa A, Folch A, Macedonio G, Giaccio B, Isaia R, Smith VC. Quantifying volcanic ash dispersal and impact of the Campanian ignimbrite super-eruption. Geophys Res Lett. 2012;39:L10310. doi:10.1029/2012GL051605.

Danhara T, Iwano H. System calibration for fission track dating of zircon using the new standard glass dosimeter IRMM-540. Fission Track News Letter. 2001;14:1-14.

Danhara T, Yamashita T, Iwano H, Kasuya M. An improved system for measuring refractive index using thermal immersion method. Quat Intern. 1992;13(14):89-91.

Danhara T, Yamashita T, Iwano H, Takemura K, Hayashida A. Chronology of the 1400-m core obtained from Lake Biwa in 1982-1983: re-investigation of fission-track ages and tephra identification. The Quat Res (Daiyonki-kenkyu). 2010;49:101-19 (In Japanese with English abstract).

Dickinson WR. Potash-depth (K-h) relations in continental margins and intra-oceanic magmatic arcs. Geology. 1975;3:53-6.

Dickinson WR, Hatherton T. Andesite volcanism and seismicity around the Pacific. Science. 1967;157:801-3.

Domitsu H, Shiihara M, Torii M, Tsukawaki S, Oda M. Tephrostratigraphy of the piston cored sediment KT96-17 P-2 in the southern Japan Sea-the eruption age of Daisen-Kusatanihara pumice (KsP). J Geol Soc Japan. 2002;108:545-56 (In Japanese with English abstract).

Eiriksson J, Larsen G, Knudsen KL, Heinemeier J, Simonarson LA. Marine reservoir age variability and water mass distribution in the Iceland Sea. Quat Sci Rev. 2004:23:2247-68

Fujioka K. History of the explosive volcanism of the Tohoku arc from core sediment samples of the Japan Trench. J Volcanol Soc Japan. 1983;28:41-58 (In Japanese with English abstract).

Fujioka K, Matsuo Y, Nishimura A, Koyama M, Radolfo K. Tephras of the Izu-Bonin forearc (Sites 787, 792, and 793). Proc ODP, Sci Results. 1992a;126:47-74.

Fujioka K, Nishimura A, Matsuo Y, Rodolfo K. Correlation of Quaternary tephras throughout the Izu-Bonin areas. Proc ODP, Sci Results. 1992b;126:23-45.

Furuta T, Fujioka K, Arai F. Widespread submarine tephras around Japan-petrographic and chemical properties. Mar Geol. 1986;72:125-42.

Hiranaka H, Kurokawa K, Yanagisawa Y. Tephrostratigraphy and diatom biostratigraphy of the Miocene Nomura Formation in the Tsugawa area,
Niigata, Japan. Bull Geol Surv Japan. 2007:58:133-88 (In Japanese with English abstract)

Hunt JE, Wynn RB, Talling PJ, Masson DG. Turbidite record of frequency and source of large volume $\left(>100 \mathrm{~km}^{3}\right)$ Canary Island landslides in the last $1.5 \mathrm{Ma}$ : implications for landslide triggers and geohazards. Geochem Geophys Geosyst. 2013;14:2100-23.

Hutchinson I, James TS, Reimer PJ, Bornhold BD, Clague JJ. Marine and limnic radiocarbon reservoir corrections for studies of late- and postglacial environments in Georgia Basin and Puget Lowland, British Columbia, Canada and Washington, USA. Quat Res. 2004;61:193-203.

Ikehara K. Sedimentological map of Hyuga-nada. Mar Geol Map series. 2000;54:37. Geological Survey of Japan. (In Japanese with English abstract).

Ikehara K. Late Quaternary seasonal sea-ice history of the northern Japan Sea. J Oceanog. 2003;59:585-93.

Ikehara K. Sedimentological Map offshore of Cape Noma-misaki. Mar Geo Map Series. 2013;79 (CD):58. Geological Survey of Japan, AIST. (In Japanese with English abstract)

Ikehara K. Marine tephra: present status and problems on its recognition, description, sampling, identification and correlation. J Volcanol Soc Japan. 2015;60:181-5 (In Japanese with English abstract).

Ikehara K, Fujine K. Fluctuations in the Late Quaternary East Asian winter monsoon recorded in sediment records of surface water cooling in the northern Japan Sea. J Quat Sci. 2012;27:866-72.

Ikehara K, Okazaki Y. Reconstruction of spatio-temporal variation of marine reservoir effect based on radiocarbon age determination of marine tephra. The Earth Monthly. 2014;35:523-8 (In Japanese).

Ikehara K, Kikkawa K, Katayama H, Seto K. Late Quaternary paleoceanography of the Japan Sea; a tephrochronological and sedimentological study. Proc. 1994 $29^{\text {th }}$ IGC Pt. B: 229-35.

Ikehara K, Kikkawa K, Chun JH. Origin and correlation of three tephras that erupted during oxygen isotope stage 3 found in cores from the Yamato Basin, central Japan Sea. The Quat Res (Daiyonki-kenkyu). 2004;43:201-12 (In Japanese with English abstract).

Ikehara M, Murayama M, Tadai O, Hokanishi N, Daido N, Kawahata H, et al. Late Quaternary tephrostratigraphy of two IMAGES cores taken from the off Shikoku in the Northwest Pacific. Fossils (Kaseki). 2006;79:60-76 (In Japanese with English abstract).

Ikehara K, Danhara T, Yamashita T, Tanahashi M, Morita S, Ohkushi K. Paleoceanographic control on a large marine reservoir effect offshore of Tokai, south of Japan, NW Pacific, during the last glacial maximum-deglaciation. Quat Intern. 2011;246:213-21.

Ikehara K, Ohkushi K, Noda A, Danhara T, Yamashita T. A new local marine reservoir correction for the last deglacial period in the Sanriku region, northwestern North Pacific, based on radiocarbon dates from the Towada-Hachinohe (To-H) tephra. The Quat Res (Daiyonki-kenkyu). 2013;52:127-37.

Itaki T, Ikehara K, Motoyama I, Hasegawa S. Abrupt ventilation changes in the Japan Sea over the last $30 \mathrm{ky}$ : evidence from deep-dwelling radiolarians. Palaeogeogr Palaeoclimat Palaeoecol. 2004;208:263-78.

Iwano H, Danhara T. A re-investigation of the geometry factors for fission-track dating of apatite, sphene and zircon. In: Van den Haute P, De Corte F (eds) Advances in fission-track geochronology. Kluwer; 1998. p. 47-66.

Kido Y, Minami I, Tada R, Fujine K, Irino T, Ikehara K, et al. Orbital-scale stratigraphy and high-resolution analysis of biogenic components and deep-water oxygenation conditions in the Japan Sea during the last 640 kyr. Palaeogeogr Palaeoclimat Palaeoecol. 2007;247:32-49.

Kimura JI, Kunikiyo T, Osaka I, Nagao T, Yamauchi S, Kakubuchi S, et al. Late Cenozoic volcanic activity in the Chugoku area, southwest Japan arc during back-arc basin opening and reinitiation of subduction. Island Arc. 2003;12:22-45.

Kimura Jl, Stern RJ, Yoshida T. Reinitiation of subduction and magmatic responses in SW Japan during Neogene time. GSA Bull. 2005;117:969-86.

Kimura JI, Nagahashi Y, Satoguchi Y, Qing C. Origins of felsic magmas in Japanese subduction zone: Geochemical characterizations of tephra from caldera-forming eruptions <5 Ma. Geochem Geophys Geosys. 2015;16:2147-74. doi:10.1002/2015GC005854.

Kotaki A, Katoh S, Kitani K. Correlation of Middle Pleistocene crystal-rich tephra layers from Daisen Volcano, southwest Japan, based on the chemical composition and refractive index of mafic minerals. Quat Intern. 2011;246:105-17

Kuno $\mathrm{H}$. Lateral variation of basalt magma type across continental margin and island arcs. Bull Volcanol. 1966;24:195-222. 
Kutterolf S, Freundt A, Perez W. Pacific offshore record of plinian arc volcanism in Central America: 2. Tephra volumes and erupted masses. Geochem Geophys Geosys. 2008a;9:Q02S02. doi:10.1029/2007GC001791.

Kutterolf S, Freundt A, Perez W, Morz T, Schacht U, Wehrmann H, et al. Pacific offshore record of plinian arc volcanism in Central America: 1. Along-arc correlations. Geochem Geophys Geosys. 2008b;9:10.1029/2007GC001631.

Kutterolf S, Schindlbeck JC, Scudder RP, Murray RW, Pickerling KT, Freundt A, et al. Large volume submarine ignimbrites in the Shikoku Basin: An example for explosive volcanism in the Western Pacific during the Late Miocene. Geochem Geophys Geosys. 2014;15:1837-51. doi:10.1002/2014GC005263.

Kuwae M, Yoshikawa S, Inouchi Y. A diatom record for the past 400 ka from Lake Biwa in Japan correlates with global paleoclimatic trends. Palaeogeogr Palaeoclimat Palaeoecol. 2002;183:261-74.

Larsen G, Eiriksson J, Knudsen KJ, Heinemeier J. Correlation of late Holocene terrestrial and marine tephra makers, northern Iceland: implications for reservoir age changes. Polar Res. 2006;21:283-90.

Lim C, Ikehara K, Toyoda K. Cryptotephra detection using high-resolution trace-element analysis of Holocene marine sediments, southwest Japan. Geochim Cosmochim Acta. 2008;72:5022-36.

Lim C, Toyoda K, Ikehara K, Peate D. Late Quaternary tephrostratigraphy of Baegdusan and Ulleung volcanoes using marine sediments in the Japan Sea/East Sea. Quat Res. 2013;80:76-87.

Lowe DJ. Tephrochronology and its application: a review. Quat Geochronol. 2011;6:107-53.

Machida H. History of explosive volcanic eruption and future prediction. In: Japan Assoc Quat Res (ed.) Quaternary research looks at the future of nature in Japan. Tokyo: Kokon-shoin; 1987. p. 104-35 (In Japanese).

Machida $\mathrm{H}$. The stratigraphy, chronology and distribution of distal marker-tephras in and around Japan. Global Plant Change. 1999;21:71-94.

Machida H, Arai F. Extensive ash falls in and around the Sea of Japan from large late Quaternary eruptions. J Volcanol Geotherm Res. 1983;18:151-64.

Machida H, Arai F. A review of late Quaternary deep-sea tephras around Japan. The Quat Res (Daiyonki-kenkyu). 1988;26:227-42 (In Japanese with English abstract).

Machida H, Arai F. Atlas of tephra in and around Japan, revised edition. Tokyo: Univ. Tokyo Press; 2003. p. 336. In Japanese.

Machida H, Arai F, Lee BS, Moriwaki H, Furuta T. Late Quaternary tephras in Ulreung-do island. J Geogr (Chigaku Zasshi). 1984;93:1-14 (In Japanese with English abstract).

Masson DG. Catastrophic collapse of the volcanic island of Hierro 15 ka ago and the history of landslides in the Canary Islands. Geology. 1996;24:231-4.

Moriwaki H, Suzuki T, Murata M, Ikehara M, Machida H, Lowe DJ. Sakurajima-Satsuma (Sz-S) and Noike-Yumugi (N-Ym) tephras: New tephrochronological marker beds for the last deglaciation, southern Kyushu, Japan. Quat Intern. 2011;246:203-12.

Nagahashi $Y$, Ishiyama A. Reconstruction of the chronological records and the major elements composition of glass shards containing in tephra beds from the NJ 88 sediment core sample, Lake Nojiri-ko, Nagano Prefecture. Rep Lake Nojiri-ko Palaeoloxodon naumanni Museum. 2009;17:1-57 (In Japanese with English abstract).

Nagahashi Y, Kataoka KS. Tephrology (part 1): terminology. The Quat Res (Daiyonki-kenkyu). 2014;53:103-9. In Japanese.

Nagahashi Y, Satoguchi Y. Stratigraphy of the Pliocene to Lower Pleistocene marine formations in Japan on the basis of tephra beds correlation. The Quat Res (Daiyonki-kenkyu). 2007;46:205-13.

Nagahashi Y, Satoguchi Y, Yoshikawa S. Correlation and stratigraphic eruption age of the pyroclastic flow deposits and wide spread volcanic ashes intercalated in the Pliocene-Pleistocene strata, central Japan. J Geol Soc Japan. 2000;106:51-69 (In Japanese with English abstract).

Nagahashi Y, Yoshikawa S, Miyakawa C, Uchiyama T, Inouchi Y. Stratigraphy and chronology of widespread tephra layers during the past $430 \mathrm{ky}$ in the Kinki District and the Yatsugatake Mountains: major element composition of the glass shards using EDS analysis. The Quat Res (Daiyonki-kenkyu). 2004;43: 15-35. In Japanese with English abstract.

Nagahashi Y, Sato T, Takeshita Y, Tawara T, Kumon F. Stratigraphy and chronology of widespread tephra beds intercalated in the TKN-2004 core sediment obtained from the Takano Formation, central Japan. The Quat Res (Daiyonki-kenkyu). 2007: 305-325 (In Japanese with English abstract).

Nakagawa T, Kitagawa H, Yasuda Y, Tarasov PE, Nishida K, Gotanada K, et al. Asynchronous climate changes in the North Atlantic and Japan during the Last Termination. Science. 2003;299:688-91.
Nakagawa T, Okuda M, Yonenobu H, Miyoshi N, Fujiki T, Gotanda K, et al. Regulation of the monsoon climate by two different orbital rhythms and forcing mechanisms. Geology. 2008;36:491-4.

Nakajima T, Kikkawa K, Ikehara K, Katayama H, Kikawa E, Joshima M, et al. Marine sediments and late Quaternary stratigraphy in the southeastern part of the Japan Sea-concerning the timing of dark layer deposition. J Geol Soc Japan. 1996;102:125-38 (In Japanese with English abstract).

Nishimura A, Rodolfo KS, Koizumi A, Gill J, Fujioka K. Episodic deposition of Pliocene-Pleistocene pumice from the Izu-Bonin arc, Leg. 126. Proc ODP. Sci Results. 1992;126:3-21.

Oba T. The eruption age of the Aso-4 and Ata ashes inferred from oxygen isotope stratigraphy. The Earth Monthly. 1991;13:224-7 (In Japanese).

Oba T, Kato M, Kitazato H, Koizumi I, Omura A, Sakai T, et al. Paleoenvironmental changes in the Japan Sea during the last 85,000 years. Paleoceanography. 1991;6:499-518.

Peters JL, Murray RW, Sparks JW, Coleman DS. Terrigenous matter and dispersed ash in sediment from the Caribbean Sea: results from Leg 165. Proc ODP. 2000;165:115-24

Pouclet A, Scott SD. Volcanic ash layers in the Japan Sea: tephrochronology of Site 798 and 799. Proc ODP. 1992;127/128(Pt. 2):791-803.

Satake K, Kato Y. The 1741 Oshima-Oshima eruption: extent and volume of submarine debris avalanche. Geophys Res Lett. 2001;28:427-30.

Satoguchi Y, Nagahashi Y. Tephrostratigraphy of the Pliocene to Middle Pleistocene series in Honshu and Kyushu islands, Japan. Island Arc. 2012;21:149-69.

Satoguchi Y, Nagahashi Y, Furusawa A, Yoshikawa S, Inouchi Y. The middle Pleistocene to Holocene tephrostratigraphy of the Takashima-oki core from Lake Biwa, central Japan. J Geosci Osaka City Univ. 2008;51:47-58.

Schindlbeck JC, Kutterolf S, Freundt A, Scudder RP, Pickering KT, Murray RW. Emplacement processes of submarine volcaniclastic deposits (IODP Site C0011, Nankai Trough). Mar Geol. 2013;343:115-24.

Scudder RP, Murray RW, Plank T. Dispersed ash in deeply buried sediment from the northwest Pacific Ocean: an example from the Izu-Bonin arc (ODP Site 1149). Earth Planet Sci Lett. 2009;284:639-48.

Scudder RP, Murray RW, Schindlbeck JC, Kutterolf S, Hauff F, McKinley CC. Regional-scale input of dispersed and discrete volcanic ash to the Izu-Bonin and Mariana subduction zones. Geochem Geophys Geosys. 2014;15:4369-79. doi:10.1002/2014GC005561.

Shiihara M, Torii M, Okuno M, Domitsu H, Nakamura T, Kim KH, et al. Revised stratigraphy of the Holocene tephras on Ulleung Island, South Korea, and possible correlatives for the U-Oki tephra. Quat Intern. 2011;246:222-32.

Shiihara M, Domitsu H, Torii M, Nagahashi Y, Okuno M. Stratigraphy and chronology of Holocene tephras from Ulleungdo volcano (South Korea) distributed in and around the Sea of Japan. The Quat Res (Daiyonki-kenkyu). 2013;52:225-36 (In Japanese with English abstract).

Shipboard Scientific Party. Background, objectives, and principal results, ODP Leg 127, Japan Sea. In: Tamaki K, Pisciotto K, Allan J et al. Proc ODP Intial Rep. 1990a; 127: 5-33.

Shipboard Scientific Party. Background, objectives, and principal results, ODP Leg 128, Japan Sea. In: Ingle JC Jr, Suyehiro, K, von Breymann MT et al. Proc ODP Initial Rep. 1990b; 128: 5-38.

Shirai M, Tada R, Fujioka K. Identification and chronostratigraphy of middle to upper Quaternary marker tephras occurring in the Anden coast based on comparison with ODP cores in the Sea of Japan. The Quat Res (Daiyonki-kenkyu). 1997;36:183-96 (In Japanese with English abstract).

Shirai M, Tada R, Fujioka K. Widespread tephras sampled from the middle-upper Pleistocene at eastern Japan Sea. Programme and Abstracts Japanese Assoc Quat Res. 1999;29:160-1 (In Japanese).

Shiraishi T, Arai F, Fujimoto Y. Discovery of Aso-4 ash and drift pumice of Aso-4 pyroclastic flow and Sambe-Kisuki Pumice fall deposits in the upper Quaternary of the Oga Peninsula, Akita Prefecture, Northeast Honshu, Japan. The Quat Res. 1992;31:21-7 (In Japanese with English abstract).

Siani G, Paterne M, Michel E, Sulpizio R, Sbrana A, Arnold M, et al. Mediterranean sea surface radiocarbon reservoir age changes since the last glacial maximum. Science. 2001;294:1917-20.

Sikes EL, Samson CR, Guilderson TP, Howard WR. Old radiocarbon ages in the southwest Pacific Ocean during the last glacial period and deglaciation. Nature. 2000;405:555-9.

Smith VC, Staff RA, Blockley SPE, Bronk Ramsey C, Nakagawa T, Mark DF, et al. Identification and correlation of visible tephras in the Lake Suigetsu SG06 
sedimentary archive, Japan: chronolostratigraphic markers for synchronizing of east Asian/west Pacific paleoclimate records across the last $150 \mathrm{ka}$. Quat Sci Rev. 2013;67:121-37.

Stuiver M, Braziunas TF. Modeling atmospheric ${ }^{14} \mathrm{C}$ influences and ${ }^{14} \mathrm{C}$ ages of marine samples to 10,000 BC. Radiocarbon. 1993;35:137-89.

Stuiver M, Pearson GW, Braziunas TF. Radiocarbon age calibration of marine samples back to 9000 cal year BP. Radiocarbon. 1986;28:980-1021.

Suganuma Y, Aoki K, Kanamatsu T, Yamazaki T. Tephrostratigraphy of deep-sea sediments in the Northwestern Pacific and its implications for the chronology of the past 300 kyr. The Quat Res (Daiyonki-kenkyu). 2006:45:435-50 (In Japanese with English abstract).

Sugimura A. Zonal arrangement of some geophysical and petrological features in Japan and its environs. Jour Fac Sci, Univ Tokyo. 1960;sec 2 12:133-53.

Suzuki T, Obara M, Aoki T, Murata M, Kawashima S, Kawai M, et al. Identification of Lower Pleistocene tephras under Tokyo and reconstruction of Quaternary crustal movements, Kanto Tectonic Basin, central Japan. Quat Intern. 2011;246:247-59.

Tada R. Paleoceanographic evolution of the Japan Sea. Palaeogeogr Palaeoclimat Palaeoecol. 1994;108:487-508.

Tada R. Onset and evolution of millennial-scale variability in the Asian Monsoon and its impact on paleoceanography of the Japan Sea. In: Clift P et al. (eds) Continent-Ocean Interactions within East Asian Marginal Seas. Geophys Monogr Series. 2004;149:283-98. AGU.

Tada R, Koizumi I, Cramp A, Rahman A. Correlation of dark and light layers, and the origin of their cyclicity in the Quaternary sediments from the Japan Sea. Proc ODP. 1992;127/128(Part 1):577-601.

Tada R, Irino T, Koizumi I. Land-ocean linkages over orbital and millennial timescales recorded in late Quaternary sediments of the Japan Sea. Paleoceanography. 1999;14:236-47.

Takata H, Itaki T, Ikehara K, Yamada K, Takayasu K. Significant Tsushima Warm Current during the early-middle Holocene along the San-in district coast inferred from foraminiferal profiles. The Quat Res (Daiyonki-kenkyu). 2006:45:249-56 (In Japanese with English abstract).

Tamura I, Yamazaki H, Mizuno K. Characteristics for the recognition of Pliocene and early Pleistocene marker tephras in central Japan. Quat Intern. 2008;178:85-99.

Toyokura I, Ohmura K, Arai F, Machida H, Takase N, Nakadaira K, et al. Identification of the Sambe Kisuki tephra found in marine terrace deposits along coastal areas of Hokuriku district, and its implications. The Quat Res (Daiyonki-kenkyu). 1991;30:79-90 (In Japanese with English abstract).

Ui T, Aramaki S. Relationship between chemical composition of Japanese island-arc volcanic rocks and gravimetric data. Tectonophysics. 1978;45:249-59.

Usami K, Ohi T, Hasegawa S, Ikehara K. Foraminiferal records of bottom-water oxygenation and surface-water productivity in the southern Japan Sea during 160-15 ka: associations with insolation changes. Mar Micropaleont. 2013;101:10-27.

Watanabe S, Tada R, Ikehara K, Fujine K, Kido Y. Sediment fabrics, oxygenation history, and circulation modes of Japan Sea during the Late Quaternary. Palaeogeogr Palaeoclimat Palaeoecol. 2007;247:50-64.

Yoshida T, Kimura JI, Yamada R, Acocella V, Sato H, Zhao D, Nakajima J, Hasegawa A, Okada T, Honda S, Ishikawa M, Prima ODA, Kudo T, Shibazaki B, Tanaka A, Imaizumi T. Evolution of late Cenozoic magmatism and the crust-mantle structure in the NE Japan Arc. Geol Soc London Spec. Publ. 2014; 385. doi:10.1144/SP385.15.

Yoshikawa S, Inouchi Y. Middle Pleistocene to Holocene explosive volcanism revealed by ashes of the Takashima-oki core samples from Lake Biwa, central Japan. Earth Sci (Chikyu Kagaku). 1993:47:97-109 (In Japanese with English abstract).

Yuasa M. Myojin Knoll, Izu-Ogasawara arc: submersible study of submarine pumice volcano. Bull Volcanol Soc Japan. 1995;40:277-84 (In Japanese with English abstract).

\section{Submit your manuscript to a SpringerOpen ${ }^{\circ}$ journal and benefit from:}

- Convenient online submission

- Rigorous peer review

- Immediate publication on acceptance

- Open access: articles freely available online

- High visibility within the field

- Retaining the copyright to your article

Submit your next manuscript at $>$ springeropen.com 